\title{
Terrorism and domestic tourist risk perceptions
}

\begin{abstract}
Previous research suggests that threats to security influence tourists' risk perceptions and travel decision-making. This qualitative study investigates British domestic tourists' risk perception in the light of the rapidly growing global trend of terrorism. This study yields three insights: (1) the incidence of terrorism produces an emotional response of fear and anxiety; (2) willingness to travel despite perceived travel risk varies depending on factors such as reason for travel, visual presence of security services, and the one-off nature of the attack; (3) the media's influence on travel risk perception is a function of how the media is perceived.
\end{abstract}

\section{Key words}

Terrorism risk perception domestic tourist perspective 


\section{INTRODUCTION}

International and domestic tourism has contributed significantly to the industrialization and development of many countries (Seabra et al. 2014). Its role in the integration of different nations and the generation of wealth has made it a global phenomenon. However, the tourism industry is now confronted with a number of global and domestic risks. Over the past two decades, a great number of terrorist cells have perpetrated attacks against tourist destinations in various parts of the globe. This has roused the concern and attention of practitioners and academics. The indiscriminate rise in terrorism poses a great threat to both international and domestic tourism, influencing and shaping tourists' travel risk perceptions and travel decision-making, and increasing security and safety concerns (Korstanje and Skoll 2014).

Previous studies have discussed the role terrorism plays in influencing perceived risk associated with tourism and its ability to induce fear and anxiety in prospective tourists (Drakos and Kutan 2003; Richards 2007; Kapuscinski 2014). Tourism crises, as highlighted by Seabra et al. (2013; 2014), are mostly triggered by incidents that affect destinations' reputation for safety, comfort and attractiveness. Discussing some of the socio-psychological travel motivations and cognitive processes involved in tourism, Oppermann (2000), Morakabati (2007) and Fletcher and Morakabati (2008) identified safety as a key motivational factor that significantly influences destination choice. Richards (2007) argues that the increasing incidence of terrorism acts to impair public confidence, in particular impacting on perceptions of the safety of a destination (Baker 2014).

Bassil (2014) observed that tourists' willingness to visit a destination reduces if safety and security are compromised by political instability (including war, tensions, terrorism). As confidence level drops as a result of perceived risk, tourists become more reluctant to move freely in public places due to a fear of attack. However, Morakabati (2007) argued that the effect of political problems on tourism demand varies across destinations, depending on the underlying circumstances and the intensity of the problem. As an example, Maley (2006) mentioned that there was a $12 \%$ drop in tourism demand for London, especially among the domestic market following the 7/7 bombings in 2005 and subsequent failed bombings. However, tourism in the UK recovered swiftly and experienced a rise (Katz 2006), which 
supports the assertion by Evans and Elphick (2005) that tourism always finds its way around crisis over time.

Many studies have discussed the subject of terrorism risk and risk perception and its linkage to tourism and particularly safety concerns among international tourists (e.g. Roehl and Fesenmaier 1992; Carter 1998; Sonmez et al. 1999; Morakabati 2007; Park and Reisinger 2010; Seabra et al. 2014). However, little research has been done on the linkages between involvement, terrorism risk perception, and safety concerns in terms of domestic tourism. Additionally, no study has focused on the significance of the perceived risk of terrorism, and its influence on the safety concerns and travel decisions of domestic tourists. The intention of this study is to help close this gap. This is particularly important in that the economic contribution of domestic tourism in most countries outweighs the international tourism market (Eijgelaar et al. 2008). This is true in the case of the UK where domestic tourists' spending generated 81 percent of total travel and tourism GDP in 2014. This figure is expected to grow by the year (WTTC 2015).

This paper reports on an exploratory study of British domestic tourists' risk perceptions in the light of the rapidly growing global terrorism trend. The paper begins with a literature review on the impact of terrorism on tourism, the increasing significance of risk and perceived risk in tourism, and the media's role in shaping tourists' risk perceptions.

\section{LITERATURE REVIEW}

\section{Terrorism and Tourism}

The increase in terrorism has seen a rise in the academic study of its impact on tourism (see Morakabati 2007; Korstanje and Clayton 2012; Baker 2014). Paraskevas and Arendell (2007) argue that it is no longer a question of "if" but rather "when" and "how" terrorists will strike. Baker (2014) highlights that both terrorism and tourism take place across national borders, utilise travel and communication technologies, are both heavily linked with the media and involve citizens of different countries. Although not all terrorist attacks have been targeted towards tourists, tourism destinations and tourists are seen as soft targets for terrorist activities (Paraskevas and Arendell 2007; Korstanje and Skoll 2014). Bassil (2014) suggests that the 
impact of terrorism on tourism differs from one destination to another depending on the intensity of the attack. Terrorism has nevertheless become a major concern for the industry.

The United Nations (2004) defined terrorism as "any harmful action that intended to cause death and serious damages to human body or noncombatants, when the purpose of such an act, by its nature or context, is to intimidate a population, or to compel a Government or an international organization to do or to abstain from doing any act”. Hoffman (2006) highlighted that terrorism is primarily designed to have a far-reaching psychological effect on and beyond the immediate victim(s) or object of the terrorist attack. Terrorism generates safety and security concerns, which inform tourists' perceived risk of an affected destination. Reisinger and Mavondo (2005), Batra (2008) and Seabra et al. (2012) argued that tourist risk perception has a major effect on travel decisions and travel behavior, including destination choice as tourists tend to avoid destinations with higher perceived risk.

According to well-documented record, incidences of terrorism go as far back as the late 19th century (Bergesen \& Han 2005). The Institute for Economics and Peace (IEP, 2014) however observed a steady growth in terrorism since 2000, with over 48,000 terrorist incidents claiming over 107,000 lives. Such incidents include the September 11 attack in the United States (2001), the Bali bombings in Indonesia (2002, 2005), the 7/7 London bombings (2005), the Paris attacks (2015 and 2016), and the beach resort killings in Tunisia (June 2015), just to mention a few. In 2013, 87 countries experienced almost 10,000 terrorist incidents and the number is increasing year on year (IEP, 2014). In 2014, 17,958 people were killed in terrorist attacks - a $61 \%$ increase from the previous year (IEP, 2015). 82\% of all deaths from terrorist attacks occurred in five countries - Iraq, Afghanistan, Pakistan, Nigeria and Syria (ibid). The IEP (2015) also highlighted that the global economic impact of terrorism in 2014 was equivalent to $13.4 \%$ of the world's GDP (US\$14.3 Trillion). Figure 1 illustrates the rise in terrorist incidents from 2000 to 2013. 


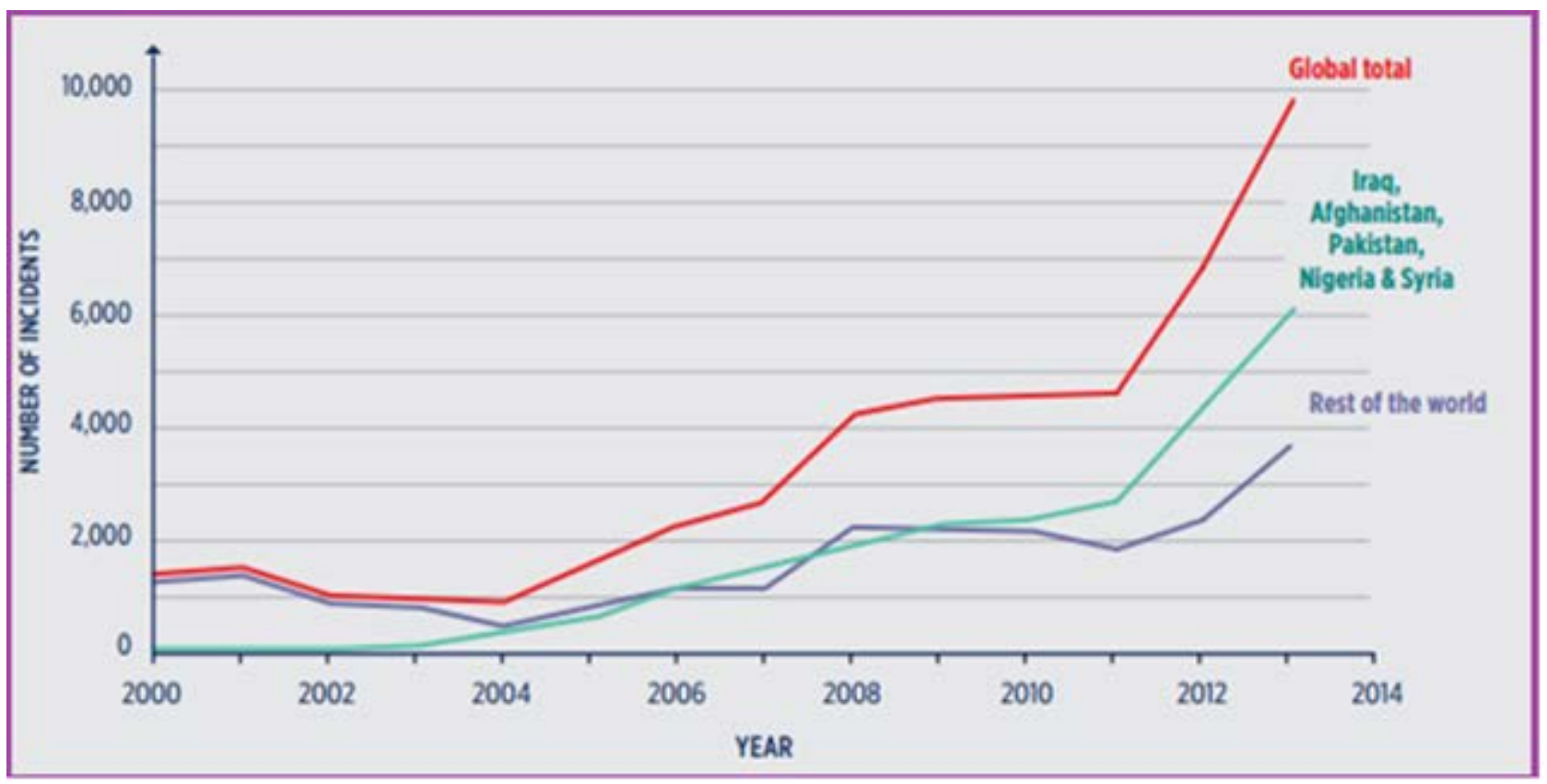

Figure 1: The rise in terrorist incidents, 2000-2013 (IEP 2014, p.13)

In recent years, tourists and tourism facilities have been deliberately targeted by terrorists. For example, in the 2002 Bali bombing (Indonesia), 202 people were killed, including many Australian tourists (Baker and Coulter 2007). In 1997 and 2005, 62 and 88 people respectively were killed in terrorist attacks in Egypt, many of whom were also tourists (Parkinson and Heyden 2015). Other recent incidents include the shooting of holiday-makers at a beachfront hotel in Tunisia in June 2015, which saw the death of 38 people, 30 of whom were Britons (ibid), and the attack in Nice, France, in 2016, which killed over 80 people. According to Baker (2014), these sorts of incidents have instilled fear and have influenced travel risk perceptions.

Weaver and Lawton (2006); Causevic and Lynch (2013) and Pratt and Liu (2016) associate tourism-directed terrorism with a number of factors. They argue that the disruption of tourist flows could have serious economic and socio-political consequences, especially at destinations heavily dependent on tourism. Furthermore, the guaranteed publicity and media coverage that attacks on tourist generate are attractive to terrorists. Santana (2004) notes that terrorists are keen to disrupt tourism, which they associate with a threat to cultural and religious values. 
Morakabati (2007) argues that one-off attacks could put a few tourists off in the short-term but that in the longer-term, people forget and tourism continues to grow. Parkinson and Heyden (2015) also suggest that not all tourists are the same, as some (especially experienced travellers) in search of exotic experiences may ignore the risk of terrorism. Morakabati adds that tourism demand will hold for high risk-associated destinations if the will to go and perceived benefits outweigh the perceived risk, though incidents of repeated attacks and threats could have a long-term impact on tourism demand (Seabra et al. 2014). Baker (2014) suggests that tourists often substitute destinations with unsafe reputations for alternative destinations perceived to be safer. On the other hand, Mansfeld and Kliot (1996) and O’Neill and Fitz (1996) argue that tourists are eager to replace insecure destination images with secure ones as risk diminishes.

\section{Risk and Risk Perception}

Compromises in safety and security at a destination can negatively influence tourists' risk perception. Chen and Noriega (2004), Reisinger and Mavondo (2005), Batra (2008), Rittichainuwat and Chakraborty (2012) and Cui et al. (2016) agree that how tourists perceive risk has a major effect on their travel decisions including destination choice. Tourists tend to avoid destinations with higher perceived risk, although other studies reveal that some tourists still travel to such destinations (Fuchs et al. 2013; Parkinson and Heyden 2015).

Risk is an integral component of human activity and everyday life. It cuts across various human endeavours including decisions on work, travel and food, though risk is believed to vary depending on perspective. Park and Reisinger (2010, p.2) define risk as "the uncertainty that consumers face when they cannot foresee the consequences of their purchase decisions". Rosa (2003, p.56) describes risk as uncertainty about a situation or event in which something of human value is at stake. Morakabati (2007, p.179) refers to risk as "a perception of the future, a perception of how threatening a scenario might be”. Lupton (1999) meanwhile suggests that risk is often associated with undesirable results even though outcomes could be favourable or unfavourable. 
Reisinger and Mavondo (2005) characterise risk by the possibility of financial, psychological, physical or social loss due to a specific perceived hazard. Other forms of risk include cultural risk, health risk, satisfaction risk, time risk, equipment risk, result risk, political risk and terrorism risk (Roehl and Fesenmaier 1992; Reisinger and Mavondo 2006; Wichasin 2011). Nyskiel (2005) categorizes the above into internal risk (e.g. health) and external risk (e.g. terrorism). Complexities however exist in addressing the subject of risk. For example, there is a school of thought that sees risk as an objective entity which can be calculated rationally regardless of subjective variables (Thompson and Dean, 1996; Taylor-Gooby and Zinn, 2006). In contrast, a contextualist view on risk, argues that risk cannot be studied independently of subjective variables such as human perceptions and experiences, a view most risk perception literature agrees with (Slovic and Weber 2002; Morakabati 2007; BenAri and Or-Chen, 2009).

Reisinger and Mavondo (2006) divide risk into absolute (real) risk and perceived (subjective) risk. They note that absolute risk is assessed by commercial providers implementing safety procedures while perceived risk is assessed by the individual in what Morakabati (2007) described as a human invention in understanding and dealing with life’s uncertainties.

\section{Risk Perception in Tourism}

Within the tourism context, risk is described as the perceptions held by tourists during the process of purchasing and consuming travel services (Tsaur et al. 1997). The nature of tourism is such that tourists' experiences can only be assessed upon purchase or consumption of the product. This is a major reason why travel products generate high uncertainty (ibid). In recent years, much empirical research has been conducted on the subject of risk perception within the tourism context (Fuchs and Reichel 2011).

Contributions from Roehl and Fesenmaier (1992) and Sonmez and Graefe (1998a, b) are among the early studies on risk perception in tourism, focusing on the relationship between tourists' travel decision making and perceived risk. Roehl and Fesenmaier's (1992) study on risk perception and travel (for tourist market segmentation) highlighted how risk perception differs among individuals as a result of varying demographic characteristics and travel 
motivation and experience. Subsequently, several studies on risk classification in tourism and travel have emerged (Maser and Weiermair 1998; Wichasin 2011). However, Dolnicar (2005) criticises the many sweeping categorizations of risk, arguing that they hinder the ability of managers to implement recommendations.

In recent years, safety and security concerns have been cited as major factors influencing perceived risk and destination choice. Of the various human-caused or natural disasters, terrorism has been observed to pose the greatest threat to the tourism industry (Reisinger and Mavondo 2006; Kozak et al. 2007). This is supported in Dolnicar's study (2005) of risk and travel decisions, which revealed that $46 \%$ of the respondents cited terrorism (as opposed to war at $18 \%$ ) as an influence on travel behaviour. However, other studies reveal that risk perception among tourists is subjective and differs from one tourist to another: what is considered risky for one might be seen as adventure for another (Dickson and Dolnicar, 2004; Fuchs et al., 2013; Seabra et al. 2013).

Reisinger and Mavondo (2006) and Williams and Baláz (2013) suggest that tourists’ risk perception may depend on a number of variables such as: the type of risk and its importance to a consumer; socio demographic factors (age, gender, and social status); psychographic factors (personality or motivation); organizational factors (travel arrangement, i.e. group versus individual travel); situation; stage of travel; individual knowledge and risk acceptance; cultural, religious and political background, and; degree of voluntary exposure to risk. Thus, “individuals may perceive the same risk in different ways” (Reisinger and Mavondo (2006, p.16).

In more recent years, the media's role in shaping people's risk perception has been highlighted. Facilitated by technological development, news coverage can be circulated and accessed around the world in a matter of minutes (Seabra et al. 2012; Kapuscinski 2014). Kapuscinski (2014) argues that the media's use of emotional appeals, vivid images, or victims' stories has made it the key source of information upon which most people rely. The media has been accused of amplifying perceived risk and bias, which are believed to inform and influence people’s risk perception of an event or a destination (Wåhlberg and Sjöberg 2000; Huang and Min 2002; Bierman 2003; Wolff and Larsen 2014). As Morakabati (2007) 
argues, however, as people's perceptions differ, so does the influence of the media on perceptions. Nevertheless, most studies agree that the media plays a vital role in influencing tourists’ risk perception and travel behaviour in the reporting of terrorism.

\section{METHODOLOGY}

This study adopts a qualitative approach to explore the travel risk perceptions of domestic tourists in the light of terrorism and its influence on their travel decisions and travel experiences. Semi-structured interviews were chosen as the best way to fulfil the research aim. Interviews allowed participants to express their thoughts and feelings freely about how their travel experiences and decision-making were affected by perceptions of risk and safety. 10 interviews were conducted, which conforms to contemporary qualitative research guidance (Altinay and Parakevas 2008; Jones et al. 2013). Furthermore, saturation was reached at the tenth interview. A purposive sampling technique was used for participant selection. As this study is centred around domestic tourists with the UK as the case study, all participants were British citizens living in the UK who took part in domestic tourism. The sample was comprised of participants of different age, gender and domestic travel experience. There were five women and five men between the ages of 21 and 67. All made at least one domestic trip annually, for leisure, VFR and business.

The highest consideration was given to ethical concerns at all stages of the study in view of the sensitivity of the subject under investigation. Ethical approval was obtained from the researchers' university ethics committee. Participants were informed of the aim of the research, they were advised of their right to withdraw from the study at any points and their informed consent was obtained. Pseudonyms are used in the reporting of findings, so that anonymity and confidentiality are maintained.

An interview guide was created, with the selection of topics and questions being influenced by the literature review. Open-ended questions were used, which allowed the researchers to engage the participants naturally and fully in conversation (Daymon and Holloway 2002). Interviews covered the following topics: terrorism and travel experience, travel risk perception and safety concerns, risk perception and travel behaviour, and media and travel 
risk perception. Interviews were conducted in a place of participants' choosing, either in their home or in their office. Interviews lasted from 30 to 45 minutes, and all were audio-recorded (subject to permission).

Interview data were analysed using thematic analysis, which involves four key stages (Jones et al. 2013). Firstly, interviews were transcribed verbatim. Secondly, transcripts were read through several times to enable familiarisation with the data. Each transcript was then subject to the process of coding. This is a laborious process, which involves the marking and labelling of discrete chunks of data so that the mass of data gathered is more manageable (Jones et al. 2013). This stage of analysis produced 24 codes. Finally a process of categorisation took place whereby these codes were organised into four conceptual categories or themes: fear and anxiety; perceived risk and destination avoidance; perceived risk and willingness to travel; and, the media and travel risk perception.

\section{FINDINGS}

\section{Fear and anxiety}

This study observed a strong emotional response to the perceived threat of terrorism during a tourist trip, with interviewees pointing to feeling worried, anxious and fearful. Responses frequently related to the London 7/7 bombing in 2005 and were linked in particular to using specific modes of transport (air, tube and bus) and to being in busy public places especially in London and other major cities. As Richards (2007) argues, there is a psychological constant at work in the effect of terrorism which causes fear and anxiety in the collective psyche. This is reflected in Millie’s comment:

"The 7/7 bombings is still really fresh in most people's mind; sometimes there is too much fear."

This view was shared by Sarah who commented on how the attack had affected her:

(With a sombre look) "It's been in my mind all the time ever since ... it makes me feel nervous....the world does not feel safe." 
Despite the fact that some of the major terrorist attacks on the UK occurred over a decade ago, they still had a lingering effect on those interviewees who described how feelings of fear and anxiety continued to affect how they felt when travelling, in particular when using public transport. This contrasts previous studies by Mansfeld and Kliot (1996) and O’Neill and Fitz (1996) which suggested that tourists are motivated to replace insecure with secure destination images as a situation calms down. As Annabel commented:

"I feel unsettled on a London bus or especially on the tube. Just a few weeks ago we went to take Mike (her husband) for medical assessment and they recommended taking the tube to get to this place. I was like, that's alright, I will drive thank you (laughs)...I would rather feel a bomb is not going to go through my car.”

Alex meanwhile pointed to a rise in vigilance especially when using public transport:

"On buses and on trains and everything, you are always on the lookout for things left unattended and stuff that you weren't before. You don't mean to but every time you look at a rucksack you think, is that just a rucksack so I'm always a little bit more anxious.”

This view was shared by Sarah who described how fear of terrorism seriously affected her travel behaviour within the UK:

"I have changed my travel behaviour as when I go to London, I never go on the tube anymore unless I really have to, and if I do I hate it, I really hate it. I would hardly ever fly now and that's more because of 9/11. So if I have to go to Scotland I wouldn't go by air because it is so much in my head, you know, what could happen....it is so frightening. So I'd rather make a long train journey than fly now."

This study suggests that the fear and anxiety effect of terrorism can linger for a long while even when a situation calms down, though participants observed one influential variable on this: the 7/7 anniversary. As one of the interviewees stated, “it puts it in your mind again”. The potential impact of the media is signalled here. 


\section{Perceived Risk and Destination Avoidance}

Despite the plethora of attractions in London, some participants mentioned being deterred from travelling there due to perceptions of danger. The vulnerability of London to attack is considered by Annabel:

"People would want to bomb somewhere with the biggest impact and so you would tend to think they would target large areas and major cities or financial institutions quite regularly. I would say terrorism has affected my travel to London. I probably would not choose to go to London...I would consider other areas first for my free time.”

Meanwhile Philippa prefers going to rural areas or smaller towns, not out of personal preference only, but also because she perceives them to be safer than major cities:

"I would be more vulnerable travelling to Brighton because it is a big city and there are lots of tourists and London too. I tend to travel more to rural areas, coastal areas, smaller towns and cities....I think they are less vulnerable targets.”

The desire to avoid or substitute destinations perceived to be vulnerable with alternative destinations perceived to be safer supports previous studies (Reisinger and Mavondo 2005; Batra 2008; Baker 2014).

For interviewees who perceived bigger cities to be vulnerable and unsafe, references were made to their previous experience of terrorism attacks, especially in London. This again serves to question the notion that tourists readily forget or replace previous destination images with secure ones. The IRA and the 7/7 bombings were often referred to, both of which had occurred over a decade ago. Philippa referred to the former to discuss her feelings about travelling to London:

"In the 1980's there was a significant Irish presence in the UK. It was the IRA and there were bomb attacks in London; it wasn't just one attack; it was a series of attacks. I think the 
experiences stayed with me. So having experienced terrorism, it has affected me for many years. I am a little bit wary and reluctant about travelling to London.”

This study however observed that the repetition and intensity of terrorist attacks could have a longer-lasting impact on tourists even though the circumstances in affected destinations might have changed. When describing past experiences of terrorism, phrases such as "a series of attacks", "lots of bombing", "quite a common thing" were used to describe the intensity and number of attacks that took place. This supports previous studies (Basil 2014; Parkinson and Heyden 2015), which suggest that cases of repeated attacks could have a long-term impact on tourists' risk perception of a destination irrespective of whether tension has eased at the destination, as previously suggested by Mansfeld and Kliot (1996) and O’Neill and Fitz (1996).

This study conversely reveals that feelings of anxiety and nervousness did not necessarily translate into behaviour, but rather they coloured the experience of the trip. There may be reluctance to travel to destinations perceived to be vulnerable and liable to risk within the UK such as London and other major cities, but trips were still made. For example, Sarah stated:

"I do still go to London, but I am always aware that there is possible danger. I mean London is like the most vulnerable place in England."

Thus, whilst some of the interviewees revealed a tendency to avoid destinations with higher perceived risk, others were willing to travel irrespective of the risk involved. As Fuchs et al. (2013) argue, not all tourists are the same, and as the next section shows, some tourists are determined not to be influenced by the threat of terrorism.

\section{Perceived Risk and Willingness to Travel}

This research observed that among some participants, there was minimal concern about travel risk in relation to terrorism for the following reasons: the one-off nature of terrorism in a destination; the presence of and confidence in the security services; a desire not to let the terrorists win or dictate their life. Again this study offers support for the notion that not all 
tourists are the same as some ignore the risk of terrorism (Morakabati 2007; Kapuscinski 2014).

For some interviewees, the one-off nature of a terrorist attack, such as the $7 / 7$ bombing signified that terrorism did not constitute a major threat. This supports the argument made by Bassil (2014) and Parkinson and Heyden (2015) that people tend to forget and ignore one-off attacks in the long-term. Callum for example felt that terrorist incidents in the UK are "more isolated cases of one-offs as opposed to something that would happen every day". Joshua felt similarly and was determined that such one-off attacks would not affect his travel plans:

"I think you've got that one incident happening which killed lots of people but it seems to be a one-off incident and I think it will be very sad for people to miss out on their holiday. I don't think it would stop me going to wherever because of one incident that happened.”

For some interviewees, there was a need to get on with life, to not give in to psychological pressure: "not allowing them to win" and "not allowing fear dictate my life" were major reasons influencing their decision to ignore the risk of terrorism. This feeling is captured in the following comments:

"I'm not really affected. No, it doesn't stop me from travelling and I wouldn't let it stop me. It's sort of a do or die aspect of life. You either stay home or do absolutely nothing or you just get on with it and you don't let it stop you and I never will let it stop me. They are not going to win and they are not going to stop me from travelling." Imogen

(With a raised voice) “These terrorists are out to frighten people big time. I would rather die than live my life in fright. If you went around worrying about everything you wouldn't actually go out of your own door.” Joshua

What emerged from the data was what could be called a 'war on terrorism', a play on the more commonly cited 'war on terror'. Despite the fact that most of the participants felt a sense of threat especially in the light of recent attacks all around Europe, they were determined not to give in to the 'enemy' 
The importance of or reason for travel was also identified as a variable influencing the willingness to travel and to ignore the risk of terrorism. Although some interviewees expressed feelings of anxiety and fear, they were nevertheless willing to travel if the reason and benefit were perceived to outweigh perceived travel risk. Philippa was willing to travel to destinations she considered vulnerable and quite unsafe if the motivation was important enough, which supports Morakabati's (2007) assertion that tourists could be willing to travel to risk-associated destinations if the will to go and perceived benefits outweigh the perceived risk:

"We would be more vulnerable travelling to Brighton because it's a big city but I might consider it if my reason for going there was so important that it outweighed any concerns about terrorism."

Some interviewees cited confidence in the security forces as a contributory factor in continuing to travel to destinations perceived to be at greater risk. The presence of security forces in increased numbers made them comfortable while travelling:

"The country is on red alert for terrorism attacks so it gives you a bit of confidence when you see a police presence in sort of train stations or stopping people. It gives you a bit of confidence." Callum

"I feel there are people who are looking at security; people are being watched, situations are being watched. So I feel reasonably secure in that." Ethan

Whilst previous experience of terrorism increased some interviewees' safety concerns, especially in big cities, others expressed a willingness to travel and showed little concern about terrorism at the destination. This begs the question as to whether repeated exposure to terrorist attacks (past or present) could make some domestic tourists learn to cope stoically with the fear that terrorism brings.

"In the 70's we had the IRA and there was a lot of bombings. I was in the fire service so we used to deal with a lot of terrorism; there was always a bomb. I've been through incidents in London in the tunnel. I've been evacuated out of places. You just get used to it; you are not surprised. You are brought up with it so it becomes a norm. We had to live with it; it's part of 
life and we just had to deal with it. So it doesn't affect me at all; it hasn't affected my travel plans at all. It won't affect my feelings of safety, no, not at all.” Oliver

"I'm not really affected. I mean I grew up in Northern Ireland during the troubles so I'm sort of used to things like that so terrorism doesn't stop me and I wouldn't let it stop me from travelling. I've certainly never been frightened by it.” Imogen

"I remember a few years back we had trouble with the IRA where they were doing bombing in London so I'm not sort of frightened to travel. I just know nothing will stop me going. I would definitely travel.” Ethan

Some of the very same interviewees went on to mention that they would not be surprised at any point if there were to be another terrorist attack within the UK and, should it happen, it would still not make any difference to their travel plans or travel experience. This supports the argument that generalisations about tourist risk perceptions cannot be made (see Reisinger and Mavondo 2005). What stops one from travelling could stimulate another to travel.

\section{The media and travel risk perception}

With reference to how the media influences domestic tourists' travel risk perceptions, most of the interviewees stated that they were not affected by the media when it comes to terrorism. This research therefore undermines generalised claims for media influence, though it is possible that participants were unaware of the influence of the media on their attitudes and feelings. Nevertheless, most participants perceived news coverage to be "exaggerated", "blown out of proportion", "quite unreliable”, and "sensationalised". This translated into a tendency not to be affected, as Imogen commented:

"You have to take media reports with a pinch of salt. I found the media can be divisive; it almost glamorises things in a way and blow things out of proportion.”

Alex also felt the media was sensationalist and stated that he was not influenced by media coverage as a result: 
"The media is a useful tool on the one hand but then again, especially the newspapers, they make their money out of sensationalism: all these horror stories, although they might be true, they are out of proportion. You've got to actually read between the lines, so no I'm not affected, not in regard to the UK."

Oliver similarly commented that the media “always hype things up so it doesn't affect me at all. They don't scare me at all. I'm not worried". For Ethan also, media coverage on terrorism often went overboard:

"Well I think often it is kind of exaggerated. I think they overplay it to some extent. I don't think it affects me really. I see it happening but I think it's just the media going over the top or going overboard about it."

Philippa was similarly sceptical of news reporting:

"I probably question some of the reliability of some of the sources, for example some of the social media sources. I don't necessarily believe that they are telling the full picture and I would want to see something corroborated a lot."

This negative judgement on media exaggeration among interviewees clearly aligns with previous studies that suggest that the media amplifies perceived risk and bias (Wåhlberg and Sjöberg 2000; Huang and Min 2002; Bierman 2003). However, whilst the same studies claim that such amplification informs or influences people's risk perception of a destination, this study reveals a more nuanced picture. The media was felt to have little or no effect on people's travel risk perception if coverage and reports are perceived to be exaggerated or overplayed. It is however important to state that there is a lot of research that indicates the influence of the media and other popular culture products on people's perceptions whether they recognise this influence or not (Wåhlberg and Sjöberg 2000; Huang and Min 2002; Bierman 2003; Kapuscinski 2014).

\section{CONCLUSION}

This exploratory study investigated domestic tourists' travel risk perceptions in the light of terrorism in the UK. This study firstly found that domestic tourists' risk perceptions are 
manifested in the form of feelings of anxiety and fear, particularly centred around the use of public transport in major cities such as London. This finding supports previous studies on terrorism by Richards (2007), Morakabati (2007) and Korstanje and Clayton (2012), which look at the psychological effects of terrorism. However, this study undermines assertions by Mansfeld and Kliot (1996) and O’Neill and Fitz (1996) that tourists tend to replace negative images and safety concerns about a destination as a situation calms down. The study found that even after many years, tourists can continue to perceive travel risk in a destination that has been hit by terrorism.

Secondly, with respect to the influence of perceived risk on domestic tourists' travel decisions and movement in public places, this study confirmed a dichotomy in relation to risk perception and travel decisions in the light of terrorism (Morakabati 2007; Batra 2008). On the one hand, there is a relationship between tourists' risk perception and travel decision making (Reisinger and Mavondo 2006), that is, tourists tend to avoid destinations with a higher perceived risk. On the other hand, this is not a generalizable point: some tourists continue to travel to destinations perceived to be unsafe (Dickson and Dolnicar 2004; Fuchs et al. 2013).

This study offers a nuanced picture: it reveals a twin reluctance to travel to destinations perceived to be unsafe, reflected in the avoidance of such destinations and a willingness to substitute them with alternative destinations perceived to be safer, as well as some willingness to travel irrespective of perceived risk of terrorism. This study identified the factors that could stimulate the decision to travel despite perceived risk: the one-off nature of previous attacks, the presence of security services, the reason for travel, the determination not to let the terrorist win, and finally, previous experiences of terrorism.

Lastly and interestingly, with reference to the media's influence on domestic tourists' travel risk perceptions, this study noted an absence of media influence on travel risk perceptions and travel decisions. This contradicts previous studies' contention that the media significantly influences tourists’ risk perceptions and travel decisions (Wåhlberg and Sjöberg 2000; Bierman 2003; Kapuscinski 2014). Furthermore, this study suggests that the media's influence on risk perceptions or travel decisions is subject to how they perceive the media. 
That is, the media may have little or no influence on domestic tourists' travel risk perceptions if coverage is perceived to be unreliable and exaggerated. Where the media was perceived to exaggerate, to glamorise, and to sensationalise terrorism, little influence was reported.

Due to the size of the sample, generalizability of the findings to other populations is not possible. As is common in qualitative research, however, the transferability of findings can be claimed (Jones et al. 2013), in that the research account might resonate with other domestic tourists in the UK. Depending on the socio-political context of the country as well as its experience of domestic terrorism, the findings could also be transferred to the domestic tourist market outside the UK. This study marks an early step in researching the impact on domestic tourists of exposure to terrorism on home soil. The knowledge base on this topic would be enriched by further research in different national contexts, and by a quantitative study of the link between perceived risk and implications for behaviour and experience. Given the value of domestic tourism to the tourism industry, it is important that this topic is further investigated. Managerial implications can be drawn from such research, which will be of high importance to industry practitioners.

\section{Study implications}

The findings have important theoretical and managerial implications. The study shows a tendency among some participants to avoid destinations perceived to be vulnerable to terrorism. Destination avoidance involves a cost to the visitor economy. Disruptions following the July 7, 2005 bombing were estimated to have cost the UK tourism industry over $£ 300$ million within the first three weeks (London Chamber of Commerce and Industry 2005). The cancellation of domestic flights and suspension of the London underground services could have contributed to these figures, but changes in consumer behavior and travel decisions played a major role in the drop in domestic travel and tourism (Theobald 2005; Simpson and Siguaw 2008). Arguably there are potential ways to help tourists cope with terrorist events if/when they occur. Studies suggest that individual preparedness and planning are effective mechanisms to help individuals cope with terrorism. A survey conducted after the $7 / 7$ bombings revealed that those who consulted government leaflets on emergency revealed a lower tendency to avoid travelling domestically especially to central London (Lee 
et al. 2009). Thus, tourists may be reassured by the provision of information, as well as by an increased security presence, as this study reveals.

This study has theoretical implications. It contributes to the literature on the impact of terrorism on risk perceptions and travel behavior by focusing on the domestic tourist market in the UK. The findings indicate the powerful emotional response to terrorism and the subsequent impact on behavior. However they also reveal that there is variation in the subjective response to risk, which needs to be taken into account. The study also calls into question the widespread assumption of media influence on risk perceptions.

The research findings of this study indicate various factors influencing willingness to travel despite perceived travel risk. Some of the factors identified in this study and highlighted in previous risk perception researches include the one-off nature of previous attacks, reason for travel, benefit(s) derived from the travel (Mansfeld and Kliot 1996; Morakabati 2007; Seabra et al. 2012). This study however identifies two other factors not often discussed in previous researches which are; the visual presence of security services and the determination not to let terrorists win in what could be seen as a "war on terrorism".

What the former (that is, visual presence of security services) demonstrates is that domestic tourists are more likely to be stimulated to travel despite perceived travel risk if there is security presence at the destination. Most of the participants identified that the presence of police officers and other form of security services around gave them a "feeling of safety" and reduced their anxiety. Although this study does not claim generalizability of this finding, however, this could possibly inform government, destination managers and industry practitioners on anxiety management among domestic tourists. This implies that in places prone to terrorist attacks, the presence of security services and checks could help re-assure the feeling of safety among domestic tourists. This may also apply to other destinations whether prone to terrorist attacks or not. 
The other factor identified in this study is participants attitude towards terrorism, that is, the determination not to let or see terrorists win. Although results from this study agree with previous studies (Chen and Noriega 2004; Rittichainuwat and Chakraborty 2012; Cui et al. 2016) on the influence of terrorism on perceived travel risk and travel decision, results from the study observed that some domestic tourists were willing to travel to destinations considered unsafe based on their disposition towards terrorism. By disposition towards terrorism, most of the participants saw their decision to travel as their own way of fighting against terrorism and not letting terrorists win. They mentioned that since the intention of terrorists is to instigate fear in people's minds, making a decision not to travel would be tantamount to giving terrorists what they want or "allowing them to win". This indicates that some domestic tourists see themselves playing a role in the fight against terrorism and their decision to travel despite perceived risk a tool. Results implication suggests that domestic tourists' may decide to travel in order to prove a point on not giving in to the fear of travelling caused by terrorist attacks. This however, might not apply to all domestic tourists (Chen and Noriega 2004; Cui et al. 2016) and decision to travel based on the feeling of not letting terrorists win or getting crippled with fear might also be a combination of other factors such as the benefit derived from traveling and the reason for traveling.

The results highlighted in this paper have identified a varying difference on the media's influence on risk perception. This study indicated that the media may have little or no influence on domestic tourists' risk perception based on how they perceived the media. That is, if the media is perceived negatively (e.g. unreliable and exaggerated), it might not necessarily influence domestic tourists’ perception of risk and travel decision. Although a lot of studies state otherwise (Wåhlberg and Sjöberg 2000; Huang and Min 2002; Bierman 2003), results from this study demonstrates that the media's influence on domestic tourists' risk perception and travel decision was based on their perception of the media. There is therefore a need to further study domestic tourists' perception of the media and how it influences their perception of risk. Although much as been said on the influence of the media on risk perception, a closer look into domestic tourists' perception of the media and its influence on risk perception would shed more light in this area. As this study indicates security presence as a key influence on feeling of safety, further studies need to be undertaken on what domestic tourists consider to be a safe destination and features they consider important for their feeling of safety. The study on which this paper is based also needs a broader and more 
geographically diverse population to identify the possible influence of nationality on domestic tourists' risk perception and to improve generalizability. The research on which this paper is based offers a potential tool to undertake a wider work on domestic tourists and exposure to terrorism.

\section{REFERENCES}

Altinay, L. and Paraskevas. A. 2008. Planning research in hospitality and tourism. London: Butterworth-Heinemann.

Baker, K. and Coulter, A. 2007. Terrorism and Tourism: The vulnerability of beach vendors' livelihoods in Bali. Journal of Sustainable Tourism, 15(3), 249-266.

Baker, D.M., 2014. The effects if terrorism on the travel and tourism industry. International Journal of Religious Tourism and Pilgrimage, 2(1), 58-67.

Bassil, C., 2014. The effect of terrorism on tourism demand in the Middle East. Peace Economics, Peace Science and Public Policy, 20(4), 669-684.

Batra, A., 2008. Foreign tourists' perception towards personal safety and potential crime while visiting Bangkok. Anatolia: An International Journal of Tourism and Hospitality Research, 19(1), 89-101.

Beirman, D., 2003. Restoring Tourism Destinations in Crisis: A Strategic Marketing Approach. Singapore: CABI Publishing.

Ben-Ari, A. and Or-Chen, K., 2009. Integrating competing conceptions of risk: A call for future direction of research. Journal of Risk Research, 12 (6), 865-877.

Bergesen, A., \& Han, Y. 2005. New directions for terrorism research. International Journal of Comparative Sociology, 46(1), 133-151.

Carter, S., 1998. Tourists' and Travellers' Social Construction of Africa and Asia as Risky Locations. Tourism Management, 19(4), 349-358.

Causevic, S. \& Lynch, P., 2013. Political (in)stability and its influence on tourism development. Tourism Management, 34(1), pp. 145-157.

Chen, R., \& Noriega, P. 2004. The impacts of terrorism: Perceptions of faculty and students on safety and security in tourism. Journal of Travel \& Tourism Marketing, 15(2/3), 81-98. 
Cui, F., Liu, Y., Chang, Y., Duan, J., and Li, J., 2016. An overview of tourism risk perception. Natural Hazards, 82(1), 643-658.

Daymon, C, and Holloway, I, 2002. Qualitative research methods in public relations and marketing communications. London: Routledge.

Dickson, T. and Dolnicar, S. 2004. No risk, no fun: The role of perceived risk in adventure tourism. In: Cooper, C. (ed.) Thirteenth international research conference of the Council of Australian University Tourism and Hospitality Education, Brisbane, Australia, 10-13 February 2004. Brisbane: Common Ground, pp.184-189.

Dolnicar, S., 2005. Understanding Barriers to Leisure Travel: Tourist Fears as a Marketing Basis. Journal of Vacation Marketing, 11(3), 197-208.

Drakos, K., \& Kutan, A. 2003. Regional effects of terrorism on tourism: Evidence from three mediterranean countries. Journal of Conflict Resolution, 47(5), 621-641.

Eijgelaar, E., Peeters, P., and Piket, P., 2008. Domestic and International tourism in a Globalized World. International Tourism Conference, International Sociological Association Jaipur. 24-26 November 2008. Accessed from: http://tourismmaster.nl/theses/Domestic_and_International_Tourism_in_a_Globalized_World.PDF

[Accessed 28 May 2014].

Evans, N., Elphick, S. (2005) Models of Crisis Management: an Evaluation of their Value for Strategic Planning in the International travel Industry. International Journal of Tourism Research, 7(3), 135-150.

Fletcher, J., \& Morakabati, Y. 2008. Tourism activity, terrorism and political instability within Commonwealth: The cases of Fiji and Kenya. International Journal of Tourism Research, 10(1), 537-556.

Fuchs, G. and Reichel, A., 2011. An Exploratory Inquiry into Destination Risk Perceptions and Risk Rreduction Strategies of First Time vs. Repeat Visitors to a Highly Volatile Destination. Tourism Management, 32(2), 266-276.

Fuchs, G., Uriely, N., Reichel, A., Maoz, D., 2013. Vacationing in a terror-stricken destination: Tourists’ risk perceptions and rationalizations. Journal of Travel Research, 52(1), 182-191.

Hoffman, B. 2006. Inside terrorism. New York: Columbia University Press. 
Huang, J., and Min, J., 2002. Earthquake Devastation and Recovery in Tourism: The Taiwan Case. Tourism Management, 23(2), 145-154.

Institute for Economics and Peace (IEP), 2014. Global Terrorism Index: measuring and understanding the impact of terrorism. New York: Institute for Economics and Peace.

Institute for Economics and Peace (IEP), 2015. Global Terrorism Index: measuring and understanding the impact of terrorism. New York: Institute for Economics and Peace.

Jones, I., Brown, L., and Holloway, I., 2013. Qualitative research in sport and physical activity. London: SAGE Publications Ltd.

Kapuscinski, G., 2014. The effects of news media on leisure tourists' perception of risk and willingness to travel, with specific reference to events of terrorism and political instability [online]. Thesis (PhD). Bournemouth University.

Katz, L., 2006. UK tourism has record year despite London bombs. The Guardian [online]. 8 November 2006. Accessed from:

http://www.theguardian.com/travel/2006/nov/08/travelnews.uknews [Accessed 18 August 2015]

Korstanje, M.E. and Clayton, A. 2012. Tourism and terrorism: conflicts and commonalities. Worldwide Hospitality and Tourism Themes, 4(1), 8-25.

Korstanje, M.E. and Skoll, G., 2014. Points of Discussion Around 09/11: Terrorism and Tourism revisited. e-Review of Tourism Research, 11(1/2), 1-17.

Kozak, M., Crotts, J., \& Law, R. 2007. The impact of perception of risk on international travellers. International Journal of Tourism Research, 9(1), 233-242.

Lee, J.E.C., Dallaire, C., \& Lemyre, L. 2009. Qualitative analysis of cognitive and contextual determinants of Canadian's individual response to terrorism: Towards a descriptive model. Health, Risk and Society, 11(5), 431 -450.

London Chamber of Commerce and Industry 2005. The Economic Effects of Terrorism on London: experiences of firms in London's business community [online]. London Chamber of Commerce and Industry: Press and Public Affairs.

Lupton, D., 1999. Risk. London: Routledge 
Maley, J., 2006. Drop in visitors as July 7 effect hits London's tourist trail. The Guardian [online]. 21 February 2006. Accessed from:

http://www.theguardian.com/uk/2006/feb/21/july7.uksecurity [Accessed 18 August 2015]

Mansfeld, Y., and Kliot, N. 1996. The Tourism Industry in the Partitioned Island of Cyprus. In: Pizam, A. and Mansfeld, Y. eds., Tourism, Crime and International Security Issues. New York: Wiley, 187-202.

Mäser, B. and Weiermair, K., 1998. Travel Decision-Making from the Vantage Point of Perceived Risk and Information Preferences. Journal of Travel and Tourism Marketing, 7(4), 107-121.

Morakabati, Y., 2007. Tourism, travel risk and travel risk perceptions: a study of travel risk perceptions and the effects of incidents on tourism [online]. Thesis ( $\mathrm{PhD})$. Bournemouth University.

Nyskiel, R., 2005. Hospitality Management Strategies. New Jersey: Prentice Hall.

O’Neill, M. A. and Fitz, F. 1996. Northern Ireland Tourism: What Chance Now? Tourism Management, 17(1), 161-163.

Oppermann, M., 2000. Where psychology and geography interface in tourism research and theory. In: Woodside, A.G., Crouch, G.I., Mazanec, J.A., Oppermann, M., and Sakai, M.Y., (eds.) Consumer psychology of tourism, hospitality and leisure. Oxon: CABI Publishing, 1937.

Paraskevas, A. and Arendell, B. 2007. A strategic framework for terrorism prevention and mitigation in tourism destinations. Tourism Management, 28(1), 1560-1573.

Park, K. and Reisinger, Y., 2010. Differences in the Perceived Influence of Natural Disasters and Travel Risk on International Travel. Tourism Geographies, 12 (1), 1-24.

Parkinson, J and Heyden, T. 2015. How terrorists attacks affect tourism. BBC [online], 29 June 2015. Accessed from: http://www.bbc.co.uk/news/magazine-33310217 [Accessed 30 June 2015 16:36:34].

Pratt, S. \& Liu, A., 2016. Does tourism really lead to peace? A global view. International Journal of Tourism Research, 18(1), 82-90.

Reisinger, Y. and Mavondo. F. 2005. Travel Anxiety and Intentions to Travel internationally: Implications of Travel Risk Perception. Journal of Travel Research, 43(3), 212-225. 
Reisinger, Y. and Mavondo, F. 2006. Cultural Differences in Travel Risk Perception. Journal of Travel \& Tourism Marketing, 20(1), 13-31.

Richards, B., 2007. Emotional Governance: politics, media and terror. Hampshire: Palgrave Macmillan.

Rittichainuwat, B.N, \& Chakraborty, G., 2012. Perceptions of importance and what safety is enough. Journal of Business Research, 65(1), 42-50.

Roehl, W.S. and Fesenmaier, D.R. 1992. Risk perceptions and pleasure travel: An exploratory analysis. Journal of Travel Research, 30(4), 17-26.

Rosa, E. A., 2003. The logical structure of the social amplification of risk framework (SARF): Metatheoretical foundation and policy implications. In: Pidgeon, N. K. \& Slovic, P. (eds). The social amplification of risk. Cambridge: Cambridge University Press.

Santana, G., 2004. Crisis Management and Tourism. Journal of Travel and Tourism Marketing, 15(4), 299-321.

Seabra, C., Abrantes, J. \& Kastenholz, E., 2012. TerrorScale: A scale to measure the contact of international tourists with terrorism. Journal of Tourism Research \& Hospitality, 1(4), 1-8.

Seabra, C., Dolnicar, S., Abrantes, J. \& Kastenholz, E., 2013. Heterogeneity in Risk and Safety Perceptions of International Tourists. Tourism Management, 36(1), 502-510.

Seabra, C., Abrantes, J.L., and Kastenholz, E., 2014. The influence of terrorism risk perception on purchase involvement and safety concern of international travellers. Journal of Marketing Management, 30(9-10), 874-903.

Simpson, P.M. and Siguaw, J. A. 2008. Perceived Travel Risks: The Traveller Perspective and Manageability. International Journal of Tourism Research, 10(4), 315-327.

Slovic, P. and Weber, E. U. 2002. Perception of Risk Posed by Extreme Events. Risk Management strategies in an Uncertain World, Palisades, New York, April 12-13, 2002.

Sonmez, S. F. and Graefe, A. R. 1998a. Influence of terrorism risk on foreign tourism decisions. Annals of Tourism Research, 25(1), 112-144.

Sonmez, S. and Graefe, A.R. 1998b. Determining future travel behaviour from past travel experience and perceptions of risk and safety. Journal of Travel Research, 37(2), 171-177. 
Sönmez, S.F., Apostolopoulos, Y., and Tarlow, P., 1999. Tourism in Crisis: managing the effects of terrorism. Journal of Travel Research, 38(1), 13-18.

Taylor-Gooby, P. and Zinn, J., 2006. Current Directions in Risk Research: New Developments in Psychology and Sociology. Risk Analysis, 26 (2), 397-411.

Theobald, W.F., 2005. Global Tourism. 3rd edition. Oxford: Elsevier ButterworthHeinemann.

Thompson, P. B. and Dean, W., 1996. Competing conceptions of risk. Health, Safety and Environment. Accessed from:

http://heinonline.org/HOL/Page?handle=hein.journals/risk7\&div=37\&g_sent=1\&collection=j ournals [Accessed 20 July 2015].

Tsaur, S.H., Tzeng, G.H., \& Wang, K.C., 1997. Evaluating tourist risks from fuzzy perspectives. Annals of Tourism Research, 24(4), 796-812.

United Nations (UN), 2004. United Nation Action to Counter Terrorisms. Available. http://www.un.org/en/terrorism/ . Accessed 21 September 2016

Wåhlberg, A. and Sjöberg, L., 2000. Risk Perception and the Media. Journal of Risk Research, 3 (1), 31-50.

Weaver, D. and Lawton, L., 2006. Tourism Management. 3rd edition. Milton: John Wiley \& Sons Australia, Ltd.

Wichasin, P., 2011. A study of risk perception and preventions of international backpackers in Thailand. International Journal of Management Cases, 9(1), 515-523.

Williams, A. \& Baláz, V., 2013. Tourism, risk tolerance and competences: Travel organization and tourism hazards. Tourism Management, 35(1), 209-221.

Wolff, K. \& Larsen, S., 2014. Can terrorism make us feel safer? Risk perceptions and worries before and after the July 22nd attacks. Annals of Tourism Research, 44(1), 200-209.

World Travel and Tourism Council (WTTC), 2015. Travel and Tourism: Economic Impacts 2015 United Kingdom. London: World Travel and Tourism Council. 